\title{
PELAYANAN POLA MAKANAN SEHAT DAN GIZI TERHADAP TAHANAN DI RUMAH TAHANAN NEGARA KELAS I DEPOK
}

\author{
Herdiana Ramadhan ${ }^{1}$, Padmono Wibowo ${ }^{2}$ \\ Email:ramadhan.herdian@gmail.com,padmonowibowo@gmail.com \\ Program Studi Manajemen Pemasyarakatan, Politeknik Ilmu Pemasyarakatan ${ }^{1,2}$
}

\begin{abstract}
Abstrak
Lembaga Pemasyarakatan dan Rumah Tahanan Negara sebagaimana yang diatur di dalam Pasal 1 Angka 1 UU Pemasyarakatan merupakan tempat dilaksanakannya penghukuman dan pembinaan bagi narapidana dengan sistem kelembagaan, pembinaan ini menjadi satu tujuan akhir dari sistem pemidanaan. Berdasarkan Pasal 14 UU Pemasyarakatan ini narapidana berhak mendapatkan pengayoman pelayanan kesehatan dan makanan yang layak. Adapun berkenaan dengan proses pelayanan konsumsi makanan untuk narapiana di dalam Lapas/Rutan, idealnya yang berdampak pada peningkatan kualitas SDM, maka dengan demikian dalam hal ini dari segi kualitas maupun kuantitas gizi harus seimbang serta layak dan aman untuk dikonsumsi. Pada kenyataannya pelayanan kesehatan dan konsumsi yang penulis teliti baik di Rutan Kelas I Depok masih kurang memadai dan belum memenuhi standar yang ditetapkan. Penelitian ini bertujuan untuk menjelaskan dan menganalisis pemenuhan hak-hak dasar narapidana atas pelayanan kesehatan dan konsumsi, faktor-faktor yang mempengaruhinya, dan upaya peningkatan pemenuhannya. Jenis penelitian hukum dan pendekatan yuridis empiris, atau penelitian hukum sosiologis. Teknik analisis data yang digunakan dalam penelitian ini ialah data kualitatif, metode kualitatif ini digunakan agar penulis dapat mengerti dan memahami gejala yang diteliti. Berdasarkan hasil penelitian penulis diketahui bahwa pelayanan kesehatan dan konsumsi di Lapas dan Rutan masih belum efektif, terlihat dari sarana dan prasarana penunjang pelayanan kesehatan, frekuensi kunjungan tenaga kesehatan, dan anggaran yang tersedia, upaya peningkatan pemenuhan nya secara internal maupun eksternal berupa sosialisasi, memperjuangkan anggaran melalui legislatif, dan optimal menjalankan aturan untuk pelayanan hak narapidana, baik pelayanan kesehatan dan makanan yang layak.
\end{abstract}

Kata Kunci : Rutan, Pola Makanan Sehat, Gizi

\begin{abstract}
Abstrack
Penitentiaries and State Detention Centers as regulated in Article 1 Number 1 of the Correctional Law is a place for punishment and guidance for inmates with an institutional system, this guidance becomes the final goal of the criminal system. Based on Article 14 of the Correctional Law, prisoners are entitled to receive adequate protection for health services and food. With regard to the process of food consumption service for prisoners in correctional institutions / detention, ideally that has an impact on improving the quality of human resources, thus in this case in terms of quality and quantity of nutrition must be balanced and appropriate and safe for consumption. In fact, the health services and consumption that the author studied at the Class I detention center in Depok were still inadequate and had not met the standards set. This study aims to explain and analyze the fulfillment of the basic rights of prisoners to health services and consumption, the factors that influence them, and efforts to increase their fulfillment. This type of legal research and empirical juridical approach, or sociological legal research. The data analysis technique used in this research is qualitative data. This qualitative method is used so that the writer can understand and understand the symptoms under study. Based on the results of the author's research, it is known that health services and consumption in prisons and detention centers are still not effective, it can be seen from the facilities and infrastructure to support health services, the frequency of visits by health workers, and the available budget, efforts to increase fulfillment internally and externally in the form of socialization, fighting for the budget. through the legislature, and optimally implement the rules for the services of prisoners' rights, both health services and adequate food.
\end{abstract}

Keyword : Detention center, Healthy Food Patterns, Nutrition 


\section{PENDAHULUAN}

Status gizi merupakan keadaan kesehatan tubuh seseorang atau sekelompok orang yang diakibatkan oleh konsumsi, penyerapan (absorpsi), dan penggunaan (utilization) zat gizi makanan. Status gizi seseorang tersebut bisa diukur dan dinilai. Dengan menilai status gizi seseorang atau sekelompok orang maka dapat diketahui apakah seseorang atau sekelompok orang tersebut status gizinya baik atau tidak baik (Riyadi,2006).

Lembaga Pemasyarakatan dan Rumah Tahanan Negara sebagaimana yang di atur di dalam Pasal 1 Angka 1 UU Pemasyarakatan merupakan tempat dilaksanakannya penghukuman dan pembinaan bagi narapidana dengan sistem kelembagaan, pembinaan ini menjadi satu tujuan akhir dari sistem pemidanaan. Pasal 14 UU No 12 Tahun 1995 Tentang Pemasyarakatan mengatur tentang hakhak dasar narapidana yang harus terpenuhi salah satu hak diantaranya adalah pelayanan kesehatan dan konsumsi di Lembaga Pemasyarakatan.

Berdasarkan Pasal $14 \quad$ UU Pemasyarakatan ini narapidana berhak mendapatkan pengayoman pelayanan kesehatan dan makanan yang layak. Adapun berkenaan dengan proses pelayanan konsumsi makanan untuk narapiana di dalam Lapas/Rutan. Idealnya yang berdampak pada peningkatan kualitas SDM, maka dengan demikian dalam hal ini dari segi kualitas maupun kuantitas gizi harus seimbang serta layak dan aman untuk dikonsumsi. UndangUndang Nomor 36 Tahun 2009 Bab VIII Pasal 142 tentang Kesehatan juga menyebutkan bahwa upaya perbaikan gizi dilakukan pada seluruh siklus kehidupan sejak dalam kandungan sampai dengan lanjut usia dengan prioritas kepada kelompok rawan. Surat Edaran Dirjen Pemasyarakatan No E.PP.02.05-02 tgl 209-2007 tentang peningkatan pelayanan makan bagi narapidana WBP baik pria maupun wanita dewasa adalah sebesar 2.250 kkal untuk energi dan 60 gram untuk protein (Republik Indonesia, 2009). Berpedoman pada pelayanan kesehatan yang diberikan di Lapas dan Rutan adalah merupakan suatu wujud pemberian HAM oleh Negara dalam konteks ini kepada warganya. Adapun penyelenggaraan pelayanan kesehatan di Lapas/Rutan dimuat dalam beberapa peraturan perundangan diantaranya :

1. UU No 39 Tahun 1999 tentang HAM.

2. UU No 12 tahun 1995 tentang Pemasyarakatan.

3. PP No 58 tahun 1999 tentang syaratsyarat dan Tata Cara Pelaksanaan Wewenang, Tugas dan Tanggung Jawab Perawatan Tahanan. 
4. Permenkumham Nomor M.HH- Teknik pengumpulan data dilakukan 01.PK.07.02 Tahun 2009 Tentang melalui penelitian lapangan dan Pedoman Penyelenggaraan Makanan kepustakaan dimana penelitian Bagi Warga Binaan Pemasyarakatan kepustakaan dilakukan dengan menelaah di Lembaga Pemasyarakatan dan peraturan perundangan, mempelajari buku Rumah Tahanan Negara.

5. Permenkumham No M.HHdan karya tulis yang relevan dengan penelitian yang diteliti. Penelitian 172.PL.02.03 Tahun 2011 tentang Pedoman Pengadaan Bahan Makanan Bagi Narapidana, Tahanan, dan Anak Didik Pemasyarakatan pada Lembaga Pemasyarakatan dan Rumah Tahanan Negara di Lingkungan

Kemenkumham.

Kondisi kesehatan tahanan dan narapidana sangatlah penting dalam melaksanakan program pembinaan bagi narapidana di Lapas. Oleh karenanya terhadap pelayanan kesehatan dan makanan yang layak dan sesuai standar kesehatan harus menjadi perhatian utama/prioritas utama dari pihak Lapas dan Rutan dalam hal ini Kepala Rumah Tahanan Negara Kelas I Depok.

\section{METODE PENELITIAN}

Penelitian ini merupakan jenis penelitian hukum dengan pendekatan yuridis empiris, atau disebut penelitian hukum sosiologis. Adapun sumber data yang digunakan dalam penelitian ini meliputi bahan hukum primer, bahan hukum sekunder dan bahan hukum tersier atau bahan hukum penunjang. Adapun lapangan laksanakan melalui wawancara dengan responden maupun informan. Dalam hal ini di identifikasikan, diolah dan dianalisis secara sistematis dengan mengolah data dengan teknik analisis data kualitatif.

\section{HASIL DAN PEMBAHASAN}

Status gizi merupakan hasil akhir dari keseimbangan antara makanan yang masuk ke dalam tubuh dengan kebutuhan tubuh akan zat gizi tersebut. Masalah gizi merupakan faktor dasar dari berbagai masalah kesehatan. Masalah gizi dapat terjadi pada seluruh kelompok umur. Status gizi seseorang dapat dipengaruhi oleh berbagai faktor seperti usia, jenis kelamin, pola konsumsi, pola aktivitas fisik dan lain sebagainya (Supariasa, 2012).

Pola makan dapat diartikan sebagai suatu kebiasaan menetap dalam hubungan dengan konsumsi makan yaitu berdasarkan jenis bahan makanan dan berdasarkan frekuensi : harian, mingguan, pernah, dan tidak pernah sama sekali. Dalam hal 
pemilihan makanan dan waktu makan manusia dipengaruhi usia, selera pribadi, kebiasaan, budaya dan sosial ekonomi (Almatsier, 2009). Tingkat kesukaan merupakan salah satu faktor yang dapat mempengaruhi konsumsi seseorang (Munggaranti, 2012). Menurut Suhardjo (1989), sikap manusia terhadap makanan banyak dipengaruhi oleh pengalamanpengalaman dan respon- respon yang diperlihatkan oleh orang lain terhadap makanan sejak masa kanak-kanak.

Penilaian pola makan dalam penelitian ini dibagi dalam dua kategori yaitu sesuai ketentuan Lapas dan tidak sesuai ketentuan. Sesuai ketentuan berarti bahwa makanan yang diterima oleh narapidana sesuai jenis, jumlah dan frekuensi makan berdasarkan ketentuan lapas. Tidak sesuai ketentuan berarti tidak sesuai jenis, jumlah ataupun frekuensi makan berdasarkan ketentuan Lapas. Menu makanan dalam Rutan Kelas I Depok dibuat berdasarkan keputusan Kementrian Hukum dan HAM tentang penyelenggaraan makan di Lapas/Rutan tahun 2009.

Dilihat dari sudut pandang Hak Asasi Manusia, Ditjen Pemasyarakatan telah berupaya memenuhi hak narapidana akan makanan dan minuman sesuai Peraturan Standar Minimum Perlakuan terhadap tahanan yang berlaku secara internasional. Hal ini dapat terlihat dari penyediaan makanan yang tepat waktu dan disajikan 3 kali sehari oleh lapas walau pun dengan menu yang disajikan kurang bervariasi dan kurang layak bila dilihat dari angka kecukupan gizi karena keterbatasan anggaran (Primawardani, 2017).

\section{Pemenuhan pelayanan pola makanan sehat dan gizi terhadap tahanan di Rutan Kelas I B Depok}

Pembahasan terkait dengan pemenuhan hak-hak dasar narapidana atas pola makanan sehat dan gizi terhadap tahanan di Rutan Kelas I B Depok dapat dianalisis menggunakan teori kewenangan, teori perlindungan hukum, dan teori pelayanan hukum. Guna menjawab permasalahan pemenuhan hak-hak narapidana di Lapas/Rutan baik terhadap kesehatan dan juga konsumsi makan dan gizi, maka dapat dicermati melalui beberapa analisis hasil wawancara dengan responden dan informan di Rumah Tahanan Negara Klas I Depok sebagai berikut. Adapun penyelenggaraan pemberian hak-hak napi untuk memperoleh pelayanan makanan sehat dan gizi di Rutan Depok sudah berjalan dengan baik, tetatpi masih ada beberapa kendala yang masih menjadi penghabat. Hal ini juga tidak hanya terjadi di Rutan Depok, namun secara umum di seluruh UPT yang 
ada di Indonesia terdapat kendala serupa. Pelayanan pola makanan sehat dan gizi belum berjalan dengan baik, berdasarkan beberapa indikator berikut:

1. Sumber daya manusia tenaga kesehatan masih kurang

Secara kuantitas dapat dinyatakan bahwa tenaga kesehatan yang tersedia di Rutan Klas I Depok sangat sedikit. Selain minimnya kuantitas yaitu jumlah tenaga kesehatan yang tersedia, kualitas kunjungan ke Rutan juga tidak memenuhi standar. Namun karena kondisi yang tidak mendukung bagi dokter untuk selalu berada di Rutan.

Berdasarkan permasalahan ini, secara sederhana solusi yang dapat ditawarkan untuk mensiasati permasalahan kualitas dan kuantitas dari dokter dan perawat tersebut adalah dibangun jaringan kerjasama antara Lapas atau Rutan dengan Dinas Kesehatan atau instansi pemerintah lainnya. Kerjasama tersebut dapat dilakukan di tingkat Provinsi maupun Kabupaten/Kota.

Dengan adanya kerjasama akan dapat menyelesaikan masalah yang terberat sekalipun. Kementerian Hukum dan HAM dapat membuat kesepakatan kerjasama dengan Departemen Kesehatan sehingga adanya hubungan yang sinergi antara.

Pusat dan daerah dalam pelaksanaan pelayanan kesehatan bagi narapidana di Lapas dan Rutan untuk warga binaan pemasyarakatan yang sehat dan memiliki semangat untuk memperbaiki kesalahan dan akhirnya dapat kembali ke masyarakat.

2. Anggaran sangat kurang

Sehubungan dengan hak narapidana terhadap pelayanan pola makanan sehat dan gizi yang baik untuk para tahanan dan kesehatan. Hak narapidana/tahanan lainnya yang ada penelitian ini adalah makanan yang layak. Kenyataan diperoleh dari kunjungan ke Rumah Tananan Negara Depok makanan yang disajikan masih kurang. Makanan bagi narapidana tidak dapat terpenuhi secara jumlah protein dan kalori yang telah ditentukan. Hal inilah yang dialami oleh narapidana warga binaan pemasyarakatan. Kurang layak makanan bagi narapidana dapat dilihat dari beberapa indikator yaitu: keluhan warga binaan pemasyarakatan atas konsumsi makanan yang kurang enak, kebersihan makanan yang kurang diperhatikan, banyak menggunakan penyedap rasa, gizi makanan yang masih kurang.

Adapun yang menjadi pedoman dalam hal keseimbangan gizi, yaitu berisikan susunan pangan sehari-hari yang di dalamnya telah termuat zat gizi dalam jenis, jumlah yang sesuai. Adapun menyangkut dengan hal penyediaan 
makanan yang diselenggarakan oleh pihak, Rutan/Lapas idealnya terpenuhi gizi seimbang, baik dalam hal kualitas maupun kuantitas yang kesemuanya ini bermuara pada terpenuhi nya gizi, kesehatan yang baik untuk peningkatan kualitas SDM. Kebutuhan energi untuk Narapidana/Tahanan yaitu berkisar 2.250 kkal dan $60 \mathrm{gr}$ protein. Gizi ialah meyangkut tentang makanan yang berdampak langsung bagi kesehatan manusia. Adapun status gizi sesorang ialah kondisi tubuh yang di akibatkan asupan, penyerapan dan penggunaan zat gizi dalam makanan. Energi dan protein merupakan suatu yang sangat berpengaruh bagi status gizi setiap individu dikarenakan menjadi penyumbang terbesar dalam tubuh. Status gizi juga menjadi hasil akhir dari keseimbangan antara makanan yang masuk ke dalam tubuh dengan kebutuhan tubuh akan zat gizi tersebut. Masalah gizi juga merupakan faktor dasar dari berbagai masalah di dalam kesehatan, hal tersebut terjadi dari berbagai kelompok umur.

Gizi yang seimbang dapat didefensikan sejumlah makanan yang mengandung berbagai zat yang dibutuhkan oleh tubuh seseorang dalam kesehariannya. Adapun kondisi kurangnya gizi dalam tubuh disebabkan ketidak seimbangan yang namanya asupan zat gizi yang salah satu diantaranya karbohidrat.
Gizi buruk ialah kurang nya asupan dalam tubuh tingkat tinggi dan kondisi ini terjadi dalam waktu yang lama. Gizi lebih merupakan kondisi kelebihan konsumsi dalam waktu lama.

Ada beberapa pedoman pelaksanaan pemenuhan makanan bagi narapidana yakni SE Menteri Kehakiman No. M.02Um.01.06 Tahun 1989, SE Dirjen PAS Kemenkumham

No.E.PP.02.05-02 Tanggal 20 September 2007, dan Surat Keputusan Menkumham No. HH01.PK.07.02 Tahun 2009 yang berkenaan dengan penyelenggaraan makanan untuk WBP.

Adapun yang menjadi kendala dihadapi oleh pihak Lembaga Pemasyarakatan dan Rumah Tahanan, ialah yang terjadi jumlah tahanan melebihi kapasitasnya, dan masalah anggaran, dimana dana yang disediakan negara masih sangat terbatas.

\section{Faktor-Faktor Yang Mempengaruhi}

Pelayalanan Pola makanan sehat dan Gizi di Rutan Depok

Jika dicermati dengan saksama, maka dapat diketahui pada saat ini, sarana dan prasarana tidak cukup karena Narapidana bertambah, oleh karena itu membutuhkan anggaran tambahan akibat adanya fenomena over kapasitas yang terjadi Lapas dan Rutan. Oleh karena nya akibat dari kondisi tersebut pihak Rutan 
mengalami berbagai kendala dalam memenuhi kebutuhan gizi bagi tahanan di karena pengelolaan makanan di dapur yang masih belum baik, baik itu di Rumah Tahanan Depok. Berdasarkan hasil penelitian penulis, yang menjadi faktor mempengaruhi pelayalanan pola makanan sehat dan Gizi di Rutan Depok antara lain:

1. Faktor sarana dan prasarana yang belum memadai.

Berdasarkan Pasal 18, Peraturan Pemerintah Republik Indonesia Nomor 58 Tahun 1999 Tentang Syarat-Syarat Dan Tata Cara Pelaksanaan Wewenang, Tugas Dan Tanggung Jawab Perawatan Tahanan, dinyatakan bahwa: Sarana dan prasarana perawatan rohani dan jasmani di fasilitas oleh pihak Lembaga Pemasyarakatan. Kenyataannya fasilitas yang tersedia baik di Lapas maupun di Rutan adalah di dalam kamar sel hanya terdapat 1 kamar mandi dan water close (WC) dan ventilasi udara yang kecil. Selain itu setiap sel yang luasnya $3 \times 5$ meter idealnya hanya menampung 3 (tiga) orang narapidana pada kenyataannya harus memuat 7 (tujuh) orang bahkan ada yang memuat 9 (sembilan) orang. Pada setiap sel tahanan terjadi kondisi over kapasitas tahanan dan narapidana, hal ini tidak sebanding luas dengan jumlah penghuninya sehingga dapat berakibat pada kondisi mudah terjangkit penyakit menular.
Banyak kekurangan sarana prasarana Rutan yang tidak akan dapat diatasi tanpa kerjasama Rutan Klas I Depok dengan pihak lainnya. Dengan bersinergi banyak yang dapat diatasi dan tanggung jawab pelayanan kesehatan narapidana menjadi memudahkan dan lebih ringan. Sehubungan dengan hal ini, maka dapat dibuat hubungan kerjasama dengan membentuk kesepahaman kerjasama diantara Depkumham dengan Dinas Kesehatan berdasarkan hasil kesepakatan, baik itu dalam bentuk tertulis maupun tidak tertulis untuk melakukan kerja sama dalam bidang pelayanan kesehatan narapidana dan jangka waktu tertentu.

2. Alokasi anggaran yang tidak cukup.

Tanpa dana yang cukup atau memadai, maka segala kegiatan akan terhambat bahkan terhenti. Namun berkaitan dengan kebutuhan makanan narapidana di Rutan tidak mungkin ditiadakan, maka yang terjadi di lapangan ialah kondisi kelayakan makanan yang disajikan kepada napi yang masih kurang layak. Sehingga timbul asumsi dari narapidana merasa diperlakukan secara tidak manusiawi dan memilih untuk tidak menjalankan pidana dan melarikan diri dari rumah tahanan negara. Apabila dikaitkan dengan kehidupan sehari-hari dalam sebuah keluarga misalnya, menu yang disajikan keluarga dalam memenuhi 
kebutuhan sehari-hari bagi anggotanya sangat dipengaruhi oleh pendapatan. Besar kecilnya pendapatan keluarga berpengaruh terhadap pola konsumsi makanan dan pola konsumsi makanan dipengaruhi pula oleh faktor sosial budaya masyarakat. Faktor utama yang mempengaruhi penyajian masakan bagi anggota keluarga ini akan menentukan penggolongan keluarga tersebut kepada keluarga yang mampu atau keluarga miskin. Kemiskinan menjadi penyebab gizi kurang, jumlah pendapatan naik maka akan berdampak pada membaik nya jenis makanan yang di pilih.

Upaya Peningkatan Pemenuhan HakHak Dasar dan Pelayanan Makanan sehat dan Gizi di Rutan

Hak kesehatan yang wajib diberikan kepada narapidana meliputi penyediaan alat-alat medis, obat-obatan, penyediaan jasa tenaga medis yang lengkap, juru masak dapur, penyimpanan makan, alat masak dan alat makan yang layak, dan penyediaan ahli gizi. Sehubungan dengan hal ini Kemenkumham melalui Dirjen Pas mengeluarkan Keputusan No. 385.PK.01.07.01 Tahun 2016 menyangkut standar perawatan paliatif bagi narapidana dan tahanan.

Penyakit yang tidak terlayani seperti gatal karena alergi makanan, mengingat makanan yang tersedia di Lapas dan Rutan berupa menu yang berlaku secara umum.
Hal ini sangat sulit bagi narapidana di Lapas dan Rutan yang menderita alergi pada sesuatu makanan. Penderita meliputi sebagian kecil dari tahanan, dan kepada tahanan tersebut diberi hak untuk berobat keluar dengan surat rujukan atau dengan biaya dari narapidana atau keluarganya bagi yang mampu. Pada Rutan tidak tersedia pelayanan kesehatan yang memadai. Oleh karena itu upaya yang dapat dilakukan dalam rangka peningkatan pemenuhan hak-hak dasar narapidana atas pelayanan kesehatan dan konsumsi di Lapas harus dilakukan secara berkelanjutan berupa upaya baik upaya yang dilakukan secara internal dan eksternal. Lapas dan Rutan dapat melakukan upaya-upaya berupa:

\section{Sosialisasi}

Negara di dalam hal ini pemerintah berkewenangan dan berkewajiban untuk mewujudkan kesejahteraan bagi warga negaranya termasuk juga para tahanan dan narapidana di Lapas dan Rutan. Rekomendasi pertama sebagai upaya yang tepat ialah menyosialisasikan menyangkut Hak WBP untuk pelayanan kesehatan seperti yang termuat di PP No. 32 tahun 1999, yang pada akhir nya tujuan Pemasyarakatan dapat tercapai.

2. Memperjuangkan Alokasi Anggaran di Legislatif

Adapun akibat dari keterbatasan 
anggaran yang tersedia ini berakibat pada belum memenuhi standar yang ditentukan, baik itu penyelenggaraan kesehatan dan makanan narapidana. PP 32 Tahun 2009 pada Pasal 14 ayat (1) dan (2), pada segi pelayanan kesehatan, sebagaimana diatur napi berkewajiban mendapatkan pemenuhan yang layak bagi kesehatan nya, yang mana tersedia medis/poliklinik dan fasilitasnya beserta sekurangkurangnya 1 orang dokter dan 1 orang tenaga kesehatan yang semua nya ini bermuara pada pelayanan yang optimal.

Dalam upaya untuk memenuhi kesehatan sebagai hak asasi manusia, implementasi penyediaan anggaran yang cukup bagi kesehatan dan juga melibatkan masyarakat luas di dalam hal ini menjadi kewajiban pemerintah. Khusus bagi narapidana dan tahanan di Lapas dan Rutan, maka tidak ada pihak yang akan memberikan perhatian apabila dari Lapas dan Rutan tidak proaktif dalam mengupayakannya. Substansi hukum adalah produk dari struktur hukum, baik peraturan yang dibuat melalui mekanisme struktur formal atau peraturan yang lahir dari kebiasaan. Substansi hukum dapat dikaji dari aspek materi UndangUndangnya, asas-asas hukum serta aktualisasi peraturan pelaksanaannya. Oleh karenanya Kepala Lapas dan Rutan harus melaksanakan tanggung jawabnya dengan baik untuk mengupayakan substansi yang diatur oleh legislatif, aturan yang berpihak dan peduli terhadap pemenuhan kesehatan dan makanan yang layak serta gizi yang baik bagi narapidana.

3. Melaksanakan peraturan yang telah ada dan mengadakan kerjasama dengan instansi.

Pemerintah dan pihak-pihak terkait lainnya sehubungan dengan pelayanan kesehatan narapidana telah terdapat suatu aturan yakni PP No 58 Tahun 1999, Serta sebagai bentuk wujud dari komitmen manifestasi perlindungan hak narapidana, dalam hal ini Menteri Hukum dan Ham mengeluarkan lagi Permen Kumham No. M.HH-172.PL.02.03 Tahun 2011. Prinsipnya pemenuhan hak dasar narapidana di Lapas dan Rutan menjadi tanggung jawab Kepala Lapas dan Rutan. Lapas dan Rutan mempunyai tanggung jawab dalam pelayanan kesehatan dan perawatan tahanan, akan tetapi kenyataannya yang terjadi di Lapas dan Rutan belum memiliki saranan dan prasarana yang memadai. Khusus di bidang perawatan tahanan misalnya sanitasi yang belum baik, tidak tersedia poliklinik bagi Narapidana dan Tahanan yang sedang mengalami sakit, pemeriksaan kesehatan yang rutin belum terlaksana, dan tidak tersedia ruangan khusus bagi narapidana dan tahanan yang 
menderita penyakit menular.

Sehubungan dengan itu, maka Departemen Hukum dan Hak Asasi Manusia (Depkumham) membentuk $M o U$ dengan instansi pemerintah (Dinas Kesehatan Provinsi Aceh) tingkat Provinsi, dan $M o U$ antara Lembaga Pemasyarakatan atau Rumah Tahanan Negara dengan Dinas Kesehatan di Kabupaten/Kota, yang ditindak lanjuti melalui perjanjian dengan menentukan langkah konkrit peran para pihak, yang memuat Standar Operasional Prosedur (SOP), mengatur pengawasan dan sanksi di dalam upaya terselenggaranya hak kesehatan bagi napi di Lapas. Sebaik apapun peraturan hukum yang sudah dibuat, namun apabila mentalitas penegak hukum kurang baik, maka akan menghambat pelaksanaan penegakan hukum tersebut. Sepanjang penelitian ini pengamatan penulis, personil di Lapas dan Rutan dari segi SDM baik kualitas maupun kuantitas masih terbatas, untuk melaksanakan pembinaan dan bimbingan keterampilan bagi Narapidana dan tahanan.

\section{PENUTUP}

Pemenuhan hak-hak dasar narapidana atas pelayanan pola makanan sehat dan gizi di Rutan masih belum efektif terlihat dari sarana dan prasarana, frekuensi kunjungan untuk pelayanan yang diberikan petugas, dan anggaran yang tersedia.

Konsumsi makanan yang disajikan sehari-hari bagi narapidana di Rutan masih kurang, hal ini dilihat dari keluhan warga binaan pemasyarakatan atas konsumsi makanan yang kurang enak, kebersihan makanan yang kurang diperhatikan, banyak menggunakan penyedap rasa serta gizi makanan yang kurang seimbang.

Adapun faktor-faktor yang sangat berpengaruh dalam pemenuhan hak dasar narapidana atas pelayanan pola makanan sehat dan gizi di Rutan antara lain: berupa over kapasitas yang terjadi di Lapas dan Rutan, sarana dan prasarana yang belum memadai, anggaran yang tersedia masih kurang memadai (terbatas), substansi perangkat aturan yang mengatur tata hubungan diantara struktur hukum belum memadai, memaksimalkan pelaksanaan tanggung jawab Kepala Lapas dan Rutan, upaya peningkatan pemenuhan hak-hak dasar narapidana atas pelayanan pola makanan sehat dan gizi di rutan baik secara internal maupun eksternal berupa sosialisasi, memperjuangkan anggaran melalui legislatif, dan melaksanakan peraturan perundang-undangan yang berkenaan dengan penyelenggaraan kesehatan dan makanan yang layak bagi Narapidana dan juga tahanan. 


\section{DAFTAR PUSTAKA}

JUSTITIA. Jurnal Ilmu Hukum dan Humaniora, 7(1), 142-156.

Abera F, Adane K. 2017. One-fourth of the prisoners are underweight in Northern Ethiopia: a crosssectional study. BMC Public Health. 17:449.

Almatsier S. 2009. Prinsip Dasar Ilmu Gizi. Jakarta: PT Gramedia Pustaka Utama.

Andari F. 2017. Hubungan asupan energy dan asupan protein dengan status gizi narapidana di Lembaga Pemasyarakatan Kelas 1 Cirebon. Skripsi. Surakarta : Universitas Muhamadiyah Surakarta.

Depkes, RI. 2009. Pedoman Penyelenggaraan Makanan di Lembaga Pemasyaraktan dan Rutan. Jakarta : Direktorat Bina Gizi Masyarakat.

Dewi, A., dkk. 2017. Hubungan Asupan Energi dan Protein dengan Status Gizi Narapidana Umum (Studi di Lembaga Pemasyarakatan Klas I Semarang Tahun 2016). FKM UNDIP. Jurnal Kesehatan Masyarakat. 5(1): 2356-3346.

Kemenkes RI. 2014. Pedoman gizi seimbang. Jakarta : Direktorat Bina Gizi Masyarakat.
Kurniawati, dkk. 2016. Faktor-faktor Yang Berhubungan dengan Terjadinya Sisa Makanan Narapidana (studi di Lembaga Pemasyarakatan Klas I Semarang). Jurnal Kesehatan Masyarakat. 4(3).

Munggaranti, Y. 2012. Analisis Tingkat Kesukaan dan Daya Terima Sarapan Sekolah terhadap Tingkat Kecukupan dan Status Gizi Siswa di SDN Kebon Kopi Bogor. Skripsi. Bogor: Departemen Gizi Masyarakat, Fakultas Ekologi Manusia, Institut Pertanian Bogor.

Firmansyah, R., Rani, F. A., \& Adwani, A. Pemenuhan Pelayanan Kesehatan dan Konsumsi Bagi Narapidana di Lapas dan Rutan. Jurnal Magister Hukum Udayana (Udayana Master Law Journal), 8(3), 433-448.

Asmarani, A., Sudayasa, I. P., \& Dewi, A. R. 2019. Pengaruh Pola Makan terhadap Status Gizi Narapidana Lapas Kelas II A Baubau. MEDULA, 6(1).

Sailan, M., \& Ilyas, I. L. 2019. Implementasi Pemenuhan Hak Mendapatkan Makanan Yang Layak Bagi Narapidana Di Lembaga Pemasyarakatan Klas 1 Makassar. Supremasi, 13(2). 